\title{
PENGARUH FAKTOR-FAKTOR EKSTERNAL DAN INTERNAL TERHADAP KINERJA USAHA KECIL DAN MENENGAH DI JAKARTA
}

\author{
Alex Sandra ${ }^{1)}$, Edi Purwanto ${ }^{2)}$ \\ ${ }^{1}$ Fakultas Ilmu Sosial dan Humaniora, Universitas Bunda Mulia \\ email: alex.zone25@yahoo.com \\ ${ }^{2}$ Fakultas Ilmu Sosial dan Humaniora, Universitas Bunda Mulia \\ email:epurwanto@bundamulia.ac.id
}

\section{ABSTRACT}

This study aims to analyse: (1) the effect of external factors on internal factors of SMEs; (2) the effect of external factors on SMEs performance; and (3) the effect of internal factors on SMEs performance in Jakarta. The result show that: (1) the external factors has positive and significant impact on internal factors of SMEs, (2) the external factors has positive but unsignificant on SMEs performance, and (3) the internal factors has positive and significant on SMEs performance in Jakarta.

Keywords: Small and Medium Enterprises, External factors, Internal factors, SMEs performance

\section{ABSTRAK}

Penelitian ini ditujukan untuk menganalisis (1) Pengaruh faktor-faktor eksternal terhadap faktor-faktor internal, (2) Pengaruh faktor-faktor eksternal terhadap kinerja Usaha Kecil dan Menengah (UKM) di Jakarta, dan (3). Pengaruh faktor-faktor internal terhadap kinerja Usaha Kecil dan Menengah (UKM) di Jakarta. Hasil penelitian menunjukan (1) Faktor-faktor eksternal yang terdiri dari aspek kebijakan pemerintah, aspek sosial budaya dan ekonomi, dan aspek peranan lembaga terkait memiliki pengaruh yang positif dan signifikan terhadap faktor-faktor internal UKM (2)Faktor-faktor eksternal memiliki pengaruh yang positif namun tidak signifikan terhadap kinerja UKM (3) Faktor-faktor internal yang terdiri dari aspek sumber daya manusia, aspek keuangan, aspek teknis dan operasional, serta aspek pasar dan pemasaran memiliki pengaruh yang positif dan signifikan terhadap kinerja UKM

Kata Kunci: Usaha Kecil Menengah, Faktor eksternal, Faktor Internal, Kinerja UKM

\section{PENDAHULUAN}

Usaha Kecil dan Menengah di Indonesia yang biasanya disingkat menjadi UKM adalah sebuah istilah yang digunakan untuk menjelaskan ukuran jenis usaha berdasarkan omset dan aset yang dimiliki usaha tersebut. Usaha kecil adalah usaha yang memiliki omset Rp.300 juta Rp.2,5 Milyar dengan aset sebesar Rp.50 juta - Rp.500 juta, sedangkan usaha menengah adalah usaha yang 
memiliki omset Rp.2,5 Milyar Rp.50 Milyar dengan aset sebesar Rp.500 juta - Rp.10 Milyar. Kementerian Koperasi dan UKM Republik Indonesia mengelompokkan usaha menjadi beberapa kategori berdasarkan Undang-Undang No. 20 Th. 2008 tentang UKM dijelaskan dalam Tabel 1.1 berikut :

Tabel 1 Klasifikasi UKM

\begin{tabular}{|c|l|c|c|}
\hline No. & $\begin{array}{l}\text { Klasifikasi } \\
\text { Usaha }\end{array}$ & Omset & Aset \\
\hline
\end{tabular}

\begin{tabular}{|c|c|c|c|}
\hline 1. & $\begin{array}{l}\text { Usaha } \\
\text { Kecil }\end{array}$ & $\begin{array}{c}\text { Rp. 300jt } \\
- \\
\text { Rp.2,5M }\end{array}$ & $\begin{array}{c}\text { Rp.50jt } \\
- \\
\text { Rp.500jt }\end{array}$ \\
\hline 2. & $\begin{array}{l}\text { Usaha } \\
\text { Menengah }\end{array}$ & $\begin{array}{c}\text { Rp.2,5M } \\
- \\
\text { Rp.50M }\end{array}$ & $\begin{array}{c}\text { Rp.500jt } \\
- \\
\text { Rp.10M }\end{array}$ \\
\hline
\end{tabular}

Sumber : http://www.depkop.go.id, 2014 (data diolah)

Sektor UKM diharapkan dapat tetap bertahan dan berkembang dengan cara seluruh pihak terkait memahami acuan yang jelas mengenai faktor-faktor apa saja yang mempengaruhi kinerja UKM. Dalam penelitian terhadap usaha kecil di Ankara, Turki oleh Acar (1993) faktor-faktor yang mempengaruhi pertumbuhan dan kinerja dari usaha digolongkan menjadi 2 kategori yaitu faktorfaktor yang berhubungan dengan lingkungan eksternal usaha dan faktor-faktor yang berhubungan dengan lingkungan internal usaha. Salah satu hasil penelitiannya menunjukkan pengaruh faktor internal terhadap kinerja usaha, yaitu usaha dengan kemampuan manajemen keuangan yang baik mengalami peningkatan pendapatan lebih tinggi dibandingkan dengan usaha yang tidak didukung oleh kemampuan manajemen keuangan yang baik. Penelitian terdahulu juga menunjukkan bahwa faktor-faktor eksternal dan internal dapat membantu perusahaan untuk menganalisis dan merencanakan strategi yang diperlukan perusahaan untuk meningkatkan posisi kompetitif perusahaan di masa depan (Capps dan Glissmeyer, 2012).

El-Chaarani (2014) melakukan penelitian tentang pengaruh faktor 
keuangan dan struktur hukum terhadap kinerja perusahaan di Eropa. Dalam penelitian terhadap 5.050 perusahaan di delapan negara berbeda di Eropa dengan sistem hukum yang berbeda menunjukkan bahwa perusahaan di negara dengan sistem hukum yang tidak terlalu ketat mengenai perlindungan terhadap investor dimanfaatkan oleh pelaku bisnis untuk menggunakan struktur modal perusahaan untuk meningkatkan keuntungan mereka. Sedangkan negara dengan sistem hukum yang lebih ketat menggunakan peraturan sebagai alat disiplin untuk mencegah praktek perampasan kekayaan.

Wei dan Lau (2008) melakukan penelitian tentang pengaruh orientasi pasar dan strategi manajemen sumber daya manusia terhadap kinerja perusahaan di Cina. Hasil penelitiannya menunjukkan bahwa orientasi pasar adalah kunci utama untuk mengembangkan strategi sumber daya manusia dan strategi sumber daya manusia memiliki dampak berkelanjutan pada kinerja perusahaan.

Oleh sebab itu, seluruh pihak yang terkait dengan UKM membutuhkan pemahaman yang jelas mengenai faktor-faktor apa saja yang perlu diperhatikan untuk mengembangkan kinerja UKM. Dimana untuk mengetahui pengaruh faktor-faktor eksternal dan internal terhadap kinerja UKM di Jakarta, akan dilakukan penelitian kuantitatif sehingga dapat diperoleh hasil pengujian pengaruh dari faktor-faktor eksternal terhadap faktor-faktor internal UKM, pengaruh dari faktor-faktor eksternal terhadap kinerja UKM, dan pengaruh dari faktor-faktor internal terhadap kinerja UKM.

Berdasarkan uraian di atas maka rumusan permasalahannya adalah sebagai berikut: (1) Apakah ada pengaruh faktor-faktor eksternal terhadap faktor-faktor internal Usaha Kecil dan Menengah (UKM) di Jakarta? (2) Apakah ada pengaruh faktor-faktor eksternal terhadap kinerja Usaha Kecil dan Menengah (UKM) di Jakarta? dan 
(3) Apakah ada pengaruh faktorfaktor internal terhadap kinerja Usaha Kecil dan Menengah (UKM) di Jakarta? Sehingga Tujuan dari penelitian ini adalah: (1) Untuk mengetahui pengaruh faktor-faktor eksternal terhadap faktor-faktor internal Usaha Kecil dan Menengah (UKM) di Jakarta; (2) Untuk mengetahui pengaruh faktor-faktor eksternal terhadap kinerja Usaha Kecil dan Menengah (UKM) di Jakarta; dan (3) Untuk mengetahui pengaruh faktor-faktor internal terhadap kinerja Usaha Kecil dan Menengah (UKM) di Jakarta.

\section{RERANGKA KONSEPTUAL DAN HIPOTESIS}

\section{Faktor-Faktor Eksternal}

Menurut Pearce dan Robinson (2011) faktor eksternal mempengaruhi sebuah perusahaan dalam menentukan arah dan tindakan yang akan dilakukan perusahaan. Faktor eksternal akan mempengaruhi struktur organisasi dan proses internal perusahaan. Faktor eksternal dibagi menjadi 3 sub kategori yang saling berkaitan yaitu: (1) Lingkungan jauh atau remote environment (ekonomi, sosial, politik, teknologi, ekologi); (2) Lingkungan industri atau industry environment (hambatan masuk, kekuatan pemasok, kekuatan pembeli, ketersediaan produk pengganti, persaingan kompetitif; dan (3) Lingkungan operasional atau operating environment (pesaing, pemberi kredit, pelanggan, pasar tenaga kerja, pemasok). Faktor eksternal yang positif akan membantu perusahaan mencapai tujuan. Perusahaan menganalisis faktor-faktor yang paling berpengaruh terhadap perusahaan dengan melihat peluang yang berada di lingkungan eksternal, dan melakukan penyesuaian dengan mempertimbangkan keadaan dan kompetensi inti perusahaan untuk mencapai tujuan (Zimmerer et. al., 2008).

\section{Faktor-faktor Internal}

Faktor internal mencakup bidang sumber daya manusia, keuangan, produksi, pemasaran, pengembangan produk, dan lain- 
lain yang memberikan gambaran nyata tentang keadaan perusahaan, menunjukkan hal-hal yang dapat digunakan untuk menciptakan kekuatan, serta menghapus hambatan demi kemajuan perusahaan. Faktor-faktor internal yang positif dapat digunakan perusahaan untuk mencapai misi, sasaran, dan tujuan. Faktor ini mencakup keterampilan atau pengetahuan, citra publik yang positif, tenaga penjualan yang berpengalaman, pelanggan yang loyal, dan faktor-faktor lainnya. Sebaliknya faktor internal yang negatif harus dihindari oleh perusahaan karena akan menghambat perusahaan dalam mencapai tujuan, misalnya kekurangan modal, kekurangan pekerja terampil, tidak mampu menguasai teknologi, dan lokasi yang tidak strategis (Zimmerer et. al.,2008). Faktor internal meliputi area fungsional bisnis, termasuk manajemen, pemasaran, keuangan/akuntansi, produksi, operasi, dan sistem informasi manajemen. Faktor internal menjadi dasar guna membangun tujuan dan strategi dalam menciptakan kekuatan dan mengatasi kelemahan organisasi (David, 2009). Dimensidimensi faktor internal meliputi: (1) aspek sumber daya manusia; (2) aspek keuangan; (3) aspek teknis dan operasional; dan (4) aspek pasar dan pemasaran.

\section{Kinerja Usaha}

Kinerja usaha dapat diukur oleh gabungan dari faktor-faktor eksternal dan internal dalam sebuah organisasi. Kedua faktor tersebut digabungkan dalam sebuah analisis SWOT, dimana faktor internal mewakili Strengths, dan Weaknesses, sedangkan faktor eksternal mewakili Opportunities, dan Threats (Rangkuti, 2013). Indikator dari kinerja usaha meliputi: pertumbuhan penjualan, modal, tenaga kerja, pemasaran, dan laba.

\section{Pengaruh}

Faktor-faktor

Eksternal terhadap Faktor-faktor

Internal

Penelitian Barney et. al. (1992)

menunjukkan bahwa pada organisasi yang berhadapan dengan 
lingkungan yang semakin sadar hukum, perusahaan melakukan adaptasi sistem produksi untuk menghadapi paparan regulasi dan hukum guna melindungi keselamatan pekerja di perusahaan dengan kegiatan produksi berbahan berbahaya.

Shamsuddoha et. al. (2009) melakukan penelitian pengaruh program promosi pemerintah terhadap kegiatan ekspor UKM. Hasilnya menunjukkan bahwa sumber daya dan kapabilitas perusahaan adalah faktor penentu, sedangkan kegiatan program promosi pemerintah hanya memfasilitasi pengembangan dari sumber daya dan kapabilitas perusahaan. Berdasarkan kajian literatur dan penelitian di atas, maka dirumuskan hipotesis penelitian sebagai berikut:

$H_{1}$ : Faktor-faktor eksternal mempunyai pengaruh positif dan signifikan terhadap faktor-faktor internal Usaha Kecil dan Menengah (UKM).
Pengaruh

Faktor-faktor Eksternal terhadap Kinerja Usaha

Dalam penelitian Wispandono (2010) disimpulkan bahwa (1) faktor-faktor lingkungan eksternal yang terdiri dari pembeli, pemasok, teknologi, pemerintah, serta faktor lingkungan internal yang terdiri dari pemasaran, keuangan, dan produksi secara simultan memiliki pengaruh yang signifikan terhadap kinerja perusahaan, (2) pembeli, pemasok, teknologi, pemasaran, dan produksi secara parsial memiliki pengaruh yang signifikan terhadap kinerja. Sedangkan pemerintah dan keuangan tidak memiliki pengaruh yang signifikan terhadap kinerja perusahaan, (3) variabel pemasaran memberikan pengaruh terbesar terhadap kinerja perusahaan.

Penelitian terdahulu Geiger dan Hoffman (1998) meneliti pengaruh regulasi pemerintah terhadap perilaku perusahaan. Hasilnya adalah terdapat hubungan positif antara lingkungan regulasi dan kinerja perusahaan. Berdasarkan kajian literatur dan penelitian di 
atas, maka dirumuskan hipotesis

penelitian sebagai berikut:

$\mathrm{H}_{2}$ : $\quad$ Faktor-faktor eksternal mempunyai pengaruh positif dan signifikan terhadap kinerja Usaha Kecil dan Menengah (UKM).

Pengaruh Faktor-faktor Internal terhadap Kinerja Usaha

Penelitian Waiganjo et. al. (2012) menunjukkan bahwa manajemen sumber daya manusia memiliki pengaruh positif terhadap kinerja organisasi. Sumber daya manusia memiliki peran penting untuk mendukung strategi organisasi dan mampu mengembangkan strategi manajemen sumber daya manusia dalam pencapaian tujuan organisasi. Perusahaan dapat memperoleh keunggulan bersaing dalam pengurangan biaya, peningkatan kualitas, inovasi, dan pencapaian tujuan melalui sumber daya manusia.

Untuk mengetahui faktor apa saja yang mempengaruhi kinerja keuangan sebuah perusahaan, Cetin
(2010) melakukan penelitian mengenai pengaruh kinerja sumber daya manusia, pemasaran, manufaktur terhadap kinerja keuangan. Hasilnya adalah kinerja manufaktur memiliki pengaruh paling kuat terhadap kinerja keuangan dibandingkan dengan faktor lain. Penemuan ini dapat digunakan oleh para manajer untuh memahami faktor apa saja yang mempengaruhi kinerja keuangan perusahaan sehingga mereka bisa memilih strategi mana yang paling tepat untuk dilakukan untuk memaksimalkan kinerja keuangan perusahaan. Berdasarkan kajian literatur dan penelitian di atas, maka dirumuskan hipotesis penelitian sebagai berikut:

$\mathrm{H}_{3}$ : Faktor-faktor internal mempunyai pengaruh positif dan signifikan terhadap kinerja Usaha Kecil dan Menengah (UKM).

Berdasarkan proposisiproposisi di atas maka dapat dibangun model penelitian seperti pada Gambar 1. 


\section{Gambar 1 Model Penelitian}

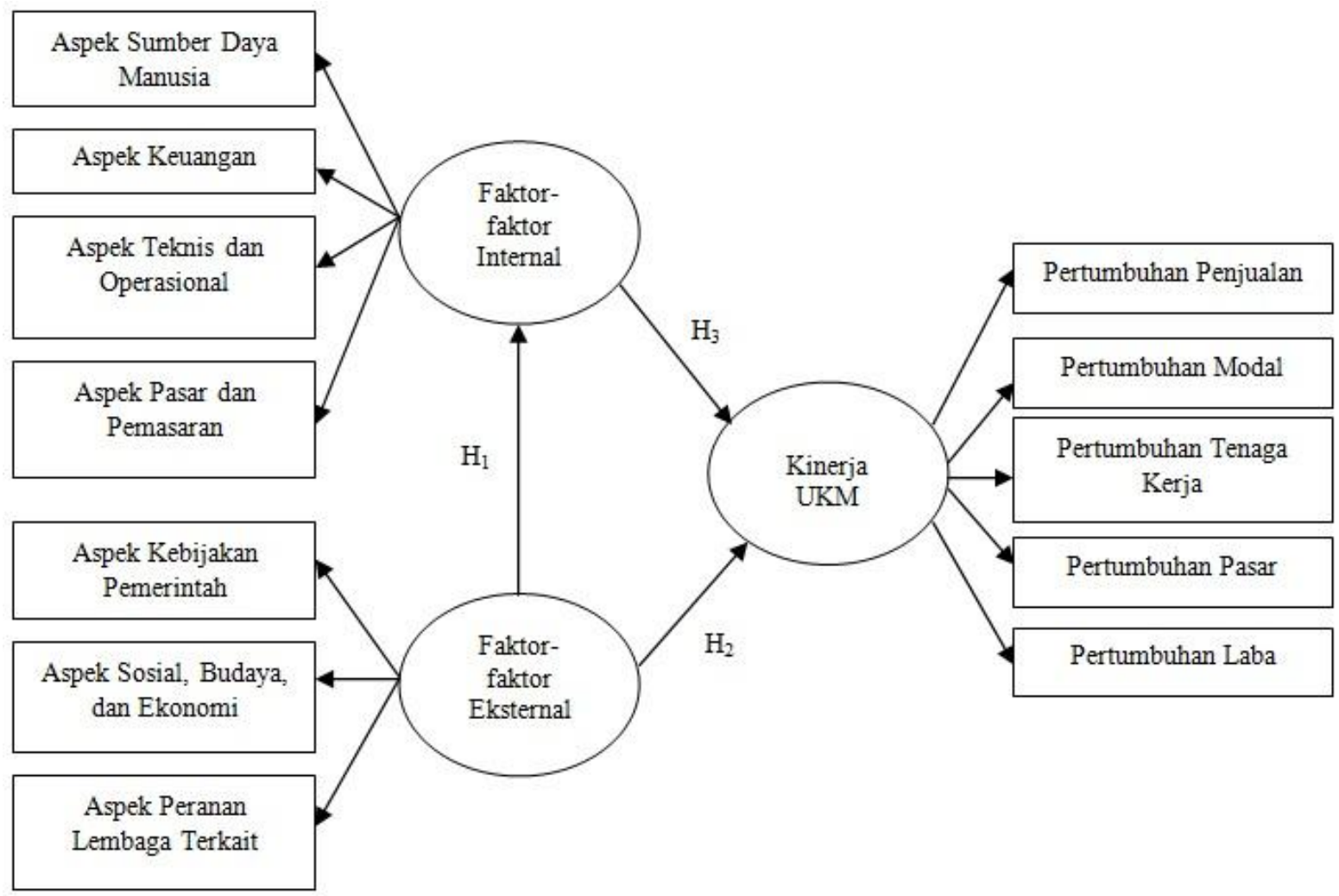

\section{METODE PENELITIAN}

Subjek penelitian dalam penelitian ini adalah UKM yang beroperasi di Jakarta. Objek penelitian adalah pengaruh faktorfaktor eksternal dan internal terhadap kinerja UKM di Jakarta dengan model dan metode analisis data yang digunakan adalah Structural Equation Modeling (SEM).

Populasi dalam penelitian ini adalah pemilik UKM di Jakarta, dengan periode pengamatan dari bulan September 2014 hingga November 2014, dengan melakukan penyebaran kuesioner selama 3 bulan pengamatan di berbagai lokasi dan pusat perbelanjaan di Jakarta. Karena keterbatasan penelitian, penarikan sampel yang digunakan dalam penelitian ini adalah menggunakan nonprobability sampling dengan jenis accidental sampling yaitu tidak semua anggota populasi berpeluang menjadi sampel dalam penelitian namun bisa saja siapapun yang 
kebetulan bertemu dijadikan sampel penelitian selama memenuhi kriteria yang diinginkan sebagai sampel yaitu UKM di Jakarta (Juliandi et.al., 2014). Jumlah sampel yang digunakan dalam penelitian ini adalah sebanyak 125 sampel.

Data dianalisis menggunakan Structural Equation Modeling (SEM) sebagai metode analisis data. SEM adalah teknik analisis statistika multivariat yang digunakan untuk menguji hubungan yang rumit antar beberapa variabel. Analisis SEM meliputi beberapa langkah yang cukup rumit, mulai dari pemeriksaan data, pengembangan model, penilaian fit model, hingga interpretasi terhadap hasil dari analisis. Dalam beberapa kasus model awal yang diajukan disarankan untuk diubah hingga beberapa kali sampai diperoleh model akhir yang bisa diterima atau fit (Dachlan, 2014).

\section{HASIL PENELITIAN DAN PEMBAHASAN}

Sebelum dilakukan pengujian model struktural dalam SEM, terlebih dahulu dilakukan pengujian model pengukuran konstruk eksogen dan endogen untuk mengetahui validitas dan reliabilitas dari setiap variabel dan sub variabel.

\section{Model Pengukuran Konstruk Eksogen}

Pada Gambar 2 model pengukuran variabel faktor-faktor eksternal dinyatakan telah memenuhi kriteria sebuah model yang fit, di mana $\chi^{2}$ (Chi-kuadrat) $\leq$ Chi-Square Table $(69,567 \leq 69,832)$, $p$-value $=0,052 \geq 0,05$, RMSEA $=$ $0,052 \leq 0,08$, GFI $=0,920 \geq 0,90$, TLI $=0,977 \geq 0,90$, dan CFI $=$ $0,982 \geq 0,95$, sehingga dapat disimpulkan model pengukuran variabel faktor eksternal memenuhi goodness-of-fit. 


\section{Gambar 2}

Analisis Faktor Konfirmatori Orde Kedua

Variabel Faktor-faktor Eksternal

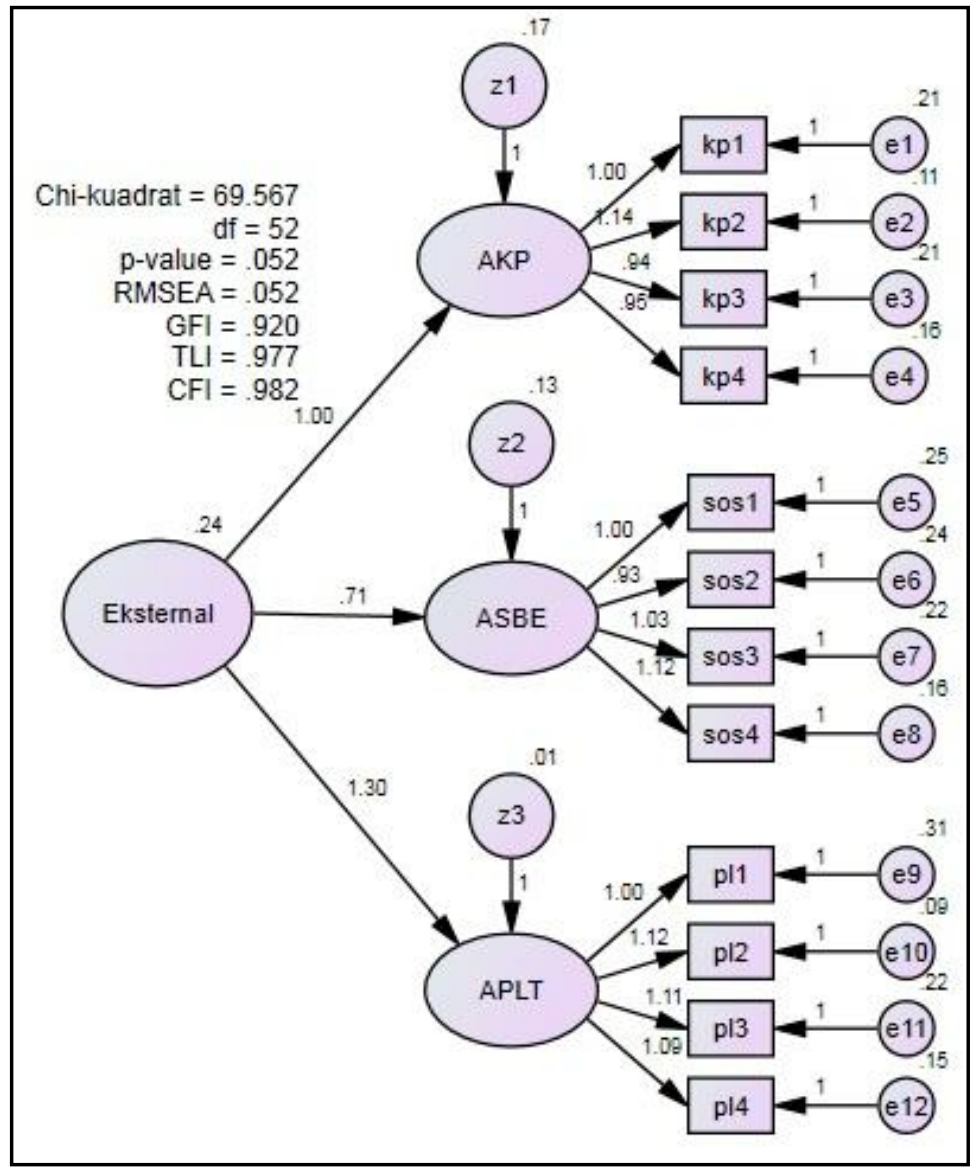

Keterangan:

AKP $=$ Aspek Kebijakan Pemerintah

ASBE = Aspek Sosial, Budaya, dan Ekonomi

APLT $=$ Aspek Peranan Lembaga Terkait

Langkah selanjutnya adalah melihat nilai signifikansi parameter dan loading faktor dari masingmasing indikator dan faktor laten yang terdapat dalam variabel faktorfaktor eksternal dapat dilihat dalam Tabel 2 sebagai berikut: 
Tabel 2 - Hasil Estimasi Unstandardized Variabel Faktor-Faktor Eksternal

\begin{tabular}{|l|l|l|r|r|r|r|}
\hline \multicolumn{2}{|c|}{} & Estimate & S.E. & C.R. & P \\
\hline AKP & $<---$ & Eksternal & 1.000 & & & \\
\hline ASBE & $<---$ & Eksternal & .715 & .130 & 5.510 & $* * *$ \\
\hline APLT & $<---$ & Eksternal & 1.298 & .177 & 7.315 & $* * *$ \\
\hline kp1 & $<---$ & AKP & 1.000 & & & \\
\hline kp2 & $<---$ & AKP & 1.136 & .093 & 12.233 & $* * *$ \\
\hline kp3 & $<---$ & AKP & .944 & .093 & 10.131 & $* * *$ \\
\hline kp4 & $<---$ & AKP & .948 & .087 & 10.885 & $* * *$ \\
\hline sos1 & $<---$ & ASBE & 1.000 & & & \\
\hline sos2 & $<---$ & ASBE & .934 & .136 & 6.894 & $* * *$ \\
\hline sos3 & $<---$ & ASBE & 1.034 & .141 & 7.314 & $* * *$ \\
\hline sos4 & $<---$ & ASBE & 1.120 & .143 & 7.854 & $* * *$ \\
\hline pl1 & $<---$ & APLT & 1.000 & & & \\
\hline p12 & $<---$ & APLT & 1.117 & .102 & 10.912 & $* * *$ \\
\hline p13 & $<---$ & APLT & 1.107 & .114 & 9.745 & $* * *$ \\
\hline p14 & $<---$ & APLT & 1.087 & .106 & 10.294 & $* * *$ \\
\hline
\end{tabular}

Sumber: Hasil estimasi dengan AMOS 20. (2014)

Nilai kritis dari p-value twotailed menyatakan bahwa variabel yang tidak signifikan sebagai pengukur konstruknya adalah > $0,05(\alpha=5 \%)$. Tiga buah asterik (***) pada kolom P menunjukkan bahwa p-value yang dihasilkan sangat kecil yaitu lebih kecil dari 0,001. Ini berarti semua relasi dinyatakan signifikan dan semua indikator dinyatakan sebagai pengukur masing-masing faktor latennya. Dan faktor laten (AKP, ASBE, dan APLT) juga dinyatakan signifikan sebagai pengukur dimensi utama yaitu Eksternal (variabel faktor-faktor eksternal).

Berikutnya Tabel 3 menampilkan hasil estimasi terstandarisir yang digunakan untuk mengukur validitas konvergen masing-masing indikator dan faktor laten dari variabel faktor-faktor eksternal. 
Tabel 3 - Hasil Estimasi Standardized Variabel Faktor-Faktor Eksternal

\begin{tabular}{|l|l|l|r|c|}
\hline \multicolumn{3}{|l|}{} & Estimate & Keterangan \\
\hline AKP & $<---$ & Eksternal & .760 & Valid \\
\hline ASBE & $<---$ & Eksternal & .696 & Valid \\
\hline APLT & $<---$ & Eksternal & .994 & Valid \\
\hline kp1 & $<---$ & AKP & .816 & Valid \\
\hline kp2 & $<---$ & AKP & .912 & Valid \\
\hline kp3 & $<---$ & AKP & .796 & Valid \\
\hline kp4 & $<---$ & AKP & .837 & Valid \\
\hline sos1 & $<---$ & ASBE & .706 & Valid \\
\hline sos2 & $<---$ & ASBE & .694 & Valid \\
\hline sos3 & $<---$ & ASBE & .742 & Valid \\
\hline sos4 & $<---$ & ASBE & .814 & Valid \\
\hline p11 & $<---$ & APLT & .755 & Valid \\
\hline p12 & $<---$ & APLT & .922 & Valid \\
\hline p13 & $<---$ & APLT & .834 & Valid \\
\hline p14 & $<---$ & APLT & .874 & Valid \\
\hline
\end{tabular}

Sumber : Hasil estimasi dengan AMOS 20. (2014)

Hasil estimasi terstandarisir berupa loading struktural dan loading faktor. Menurut Dachlan (2014) batas nilai loading minimal adalah $\geq 0,45$ untuk memenuhi validitas konvergen dan nilai loading yang diharapkan adalah $\geq$ 0,7. Dari tabel di atas semua indikator dinyatakan memenuhi validitas konvergen sebagai pengukur masing-masing faktor latennya. Dan faktor laten (AKP, ASBE, dan APLT) juga dinyatakan memenuhi validitas konvergen sebagai pengukur dimensi utama yaitu Eksternal (variabel faktorfaktor eksternal). Dalam tahap berikutnya hasil estimasi terstandarisir akan digunakan untuk menghitung realibilitas konstruk atau $C R$ dan $A V E$. Persamaan yang digunakan untuk menghitung $C R$ dan $A V E$ menggunakan persamaan berikut ini:

$$
C R=\frac{\left(\sum_{i=1}^{n} \lambda_{i}\right)^{2}}{\left(\sum_{i=1}^{n} \lambda_{i}\right)^{2}+\sum_{i=1}^{n} \varepsilon_{i}}
$$

Sumber: Dachlan (2014)

$$
A V E=\frac{\sum_{i=1}^{n} \lambda_{i}^{2}}{\sum_{i=1}^{n} \lambda_{i}^{2}+\sum_{i=1}^{n} \varepsilon_{i}}
$$

Sumber: Dachlan (2014) Hasil standarized loading data 
Eksternal $=0,760+0,696+$ Eksternal $=0,760^{2}+0,696^{2}+0,994^{2}$

$0,994=2,450$

$=2,050$

$\mathrm{AKP}=0,816+0,912+0,796+$

$\mathrm{AKP}=0,816^{2}+0,912^{2}+0,796^{2}+$

$0,837=3,361$

$0,837^{2}=2,831$

$\mathrm{ASBE}=0,706+0,694+0,742+$

$\mathrm{ASBE}=0,706^{2}+0,694^{2}+0,742^{2}+$

$0,814=2,956$

$0,814^{2}=2,193$

APLT $=0,755+0,922+0,834+$

APLT $=0,755^{2}+0,922^{2}+0,834^{2}+$

$0,874=3,385$

$0,874^{2}=2,879$

Hasil measurement error loading

data

Eksternal $=0,422+0,515+$

Hasil penghitungan $A V E$

$0,011=0,948$

$\mathrm{AKP}=0,334+0,168+0,366+$

$0,299=1,167$

$\mathrm{ASBE}=0,501+0,518+0,449+$

$0,337=1,805$

APLT $=0,429+0,149+0,304+$

$0,236=1,118$

Hasil penghitungan $C R$

Eksernal $=\frac{2450^{2}}{2,450^{2}+0,948}$

$$
=0,863
$$

$A K P=\frac{3,361^{2}}{3,361^{2}+1,671}=0,906$

$A S B E=\frac{2,956^{2}}{2,956^{2}+1,805}=0,828$

$A P L T=\frac{3,385^{2}}{3,3852^{2}+1,118}=0,911$

Hasil square standarized loading data

Eksternal $=\frac{2,050}{3}=0,683$

$A K P=\frac{2,831}{4}=0,707$

$A S B E=\frac{2,193}{4}=0,548$

$A P L T=\frac{2,879}{4}=0,719$

Hasil penghitungan $C R$ dan $A V E$ diringkas dalam Tabel 4.

Tabel 4 - Hasil Pengujian

Reliabilitas Variabel dan Sub Variabel Faktor Eksternal

\begin{tabular}{|l|c|c|c|}
\hline $\begin{array}{c}\text { Variab } \\
\text { el / Sub } \\
\text { Variab } \\
\text { el }\end{array}$ & CR & $\boldsymbol{A V E}$ & $\begin{array}{c}\text { Keteranga } \\
\mathbf{n}\end{array}$ \\
\hline $\begin{array}{l}\text { Ekstern } \\
\text { al }\end{array}$ & $\begin{array}{c}0,86 \\
3\end{array}$ & $\begin{array}{c}0,68 \\
3\end{array}$ & Reliabel \\
\hline AKP & $\begin{array}{c}0,90 \\
6\end{array}$ & $\begin{array}{c}0,70 \\
7\end{array}$ & Reliabel \\
\hline ASBE & 0,82 & 0,54 & Reliabel \\
& 8 & 8 & \\
\hline APLT & 0,91 & $\begin{array}{c}0,71 \\
1\end{array}$ & Reliabel \\
& 1 & 9 & \\
\hline
\end{tabular}


Model Pengukuran Konstruk

Endogen

Analisis Faktor Konfirmatori Orde

Kedua Variabel Faktor-faktor

Internal

Pada Gambar 3 model pengukuran variabel faktor-faktor internal telah memenuhi kriteria sebuah model yang fit. Di mana $\chi^{2}$
(Chi-kuadrat) $\leq$ Chi-Square Table $(104,980 \leq 108,648), \quad p$-value $=$ $0,080 \geq 0,05$, RMSEA $=0,042 \leq$ $0,08, \mathrm{GFI}=0,909 \geq 0,90, \mathrm{TLI}=$ $0,974 \geq 0,90$, dan $\mathrm{CFI}=0,981 \geq$ 0,90, sehingga dapat disimpulkan model pengukuran variabel faktor internal memenuhi goodness-of-fit.

\section{Gambar 3 - Analisis Faktor Konfirmatori Orde Kedua}

Variabel Faktor-Faktor Internal

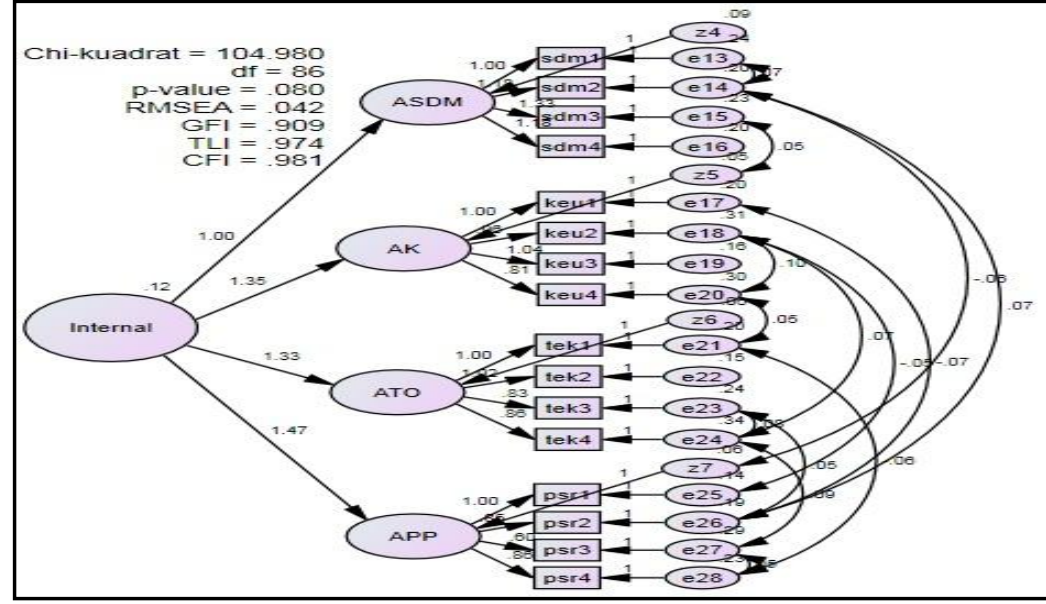

Sumber: Hasil estimasi dengan AMOS 20. (2014)

Keterangan :

ASDM= Aspek Sumber Daya Manusia

AK $=$ Aspek Keuangan

ATO = Aspek Teknis dan Operasional

APP $=$ Aspek Pasar dan Pemasaran 
Nilai signifikansi parameter dan loading faktor dari masing-masing indikator dan faktor laten yang terdapat dalam variabel faktor-faktor internal dapat dilihat dalam Tabel 5 sebagai berikut

\section{Tabel 5 - Hasil Estimasi Unstandardized Variabel Faktor-Faktor Internal}

\begin{tabular}{|l|l|l|r|r|r|l|l|l|}
\hline \multicolumn{2}{|l}{} & Estimate & \multicolumn{1}{l|}{ S.E. } & C.R. & P & Label \\
\hline ASDM & $<---$ & Internal & 1.000 & & & & \\
\hline AK & $<---$ & Internal & 1.355 & .239 & 5.668 & $* * *$ & \\
\hline ATO & $<---$ & Internal & 1.327 & .237 & 5.590 & $* * *$ & \\
\hline APP & $<---$ & Internal & 1.468 & .250 & 5.872 & $* * *$ & \\
\hline sdm1 & $<---$ & ASDM & 1.000 & & & & \\
\hline sdm2 & $<---$ & ASDM & 1.184 & .131 & 9.027 & $* * *$ & \\
\hline sdm3 & $<---$ & ASDM & 1.330 & .185 & 7.208 & $* * *$ & \\
\hline sdm4 & $<---$ & ASDM & 1.182 & .167 & 7.084 & $* * *$ & \\
\hline keu1 & $<---$ & AK & 1.000 & & & & \\
\hline keu2 & $<---$ & AK & .960 & .133 & 7.238 & $* * *$ & \\
\hline keu3 & $<---$ & AK & 1.040 & .118 & 8.781 & $* * *$ & \\
\hline keu4 & $<---$ & AK & .806 & .123 & 6.544 & $* * *$ & \\
\hline tek1 & $<---$ & ATO & 1.000 & & & & \\
\hline tek2 & $<---$ & ATO & 1.017 & .118 & 8.650 & $* * *$ & \\
\hline tek3 & $<---$ & ATO & .832 & .116 & 7.141 & $* * *$ & \\
\hline tek4 & $<---$ & ATO & .862 & .131 & 6.577 & $* * *$ & \\
\hline psr1 & $<---$ & APP & 1.000 & & & & \\
\hline psr2 & $<---$ & APP & .850 & .096 & 8.857 & $* * *$ & \\
\hline psr3 & $<---$ & APP & .597 & .100 & 5.994 & $* * *$ & \\
\hline psr4 & $<---$ & APP & .861 & .100 & 8.575 & $* * *$ & \\
\hline
\end{tabular}

Sumber: Hasil estimasi dengan AMOS 20. (2014)

Tiga buah asterik $(* * *)$ pada dinyatakan sebagai pengukur

kolom $\mathrm{P}$ menunjukkan bahwa $p$ value yang dihasilkan sangat kecil yaitu lebih kecil dari 0,001. Ini berarti semua relasi dinyatakan signifikan, semua indikator masing-masing faktor latennya. Dan faktor laten (ASDM, AK, ATO, dan APP) juga dinyatakan signifikan sebagai pengukur dimensi utama yaitu Internal (variabel faktor-faktor 
internal). Berikutnya Tabel 6 masing-masing indikator dan faktor menampilkan hasil estimasi laten dari variabel faktor-faktor terstandarisir yang digunakan untuk internal.

mengukur validitas konvergen

Tabel 6 - Hasil Estimasi Standardized

Variabel Faktor-Faktor Internal

\begin{tabular}{|l|l|l|r|c|}
\hline \multicolumn{2}{|l}{} & Estimate & Keterangan \\
\hline ASDM & $<---$ & Internal & .755 & Valid \\
\hline AK & $<---$ & Internal & .896 & Valid \\
\hline ATO & $<---$ & Internal & .878 & Valid \\
\hline APP & $<---$ & Internal & .903 & Valid \\
\hline sdm1 & $<---$ & ASDM & .682 & Valid \\
\hline sdm2 & $<---$ & ASDM & .768 & Valid \\
\hline sdm3 & $<---$ & ASDM & .788 & Valid \\
\hline sdm4 & $<---$ & ASDM & .770 & Valid \\
\hline keu1 & $<---$ & AK & .757 & Valid \\
\hline keu2 & $<---$ & AK & .669 & Valid \\
\hline keu3 & $<---$ & AK & .806 & Valid \\
\hline keu4 & $<---$ & AK & .611 & Valid \\
\hline tek1 & $<---$ & ATO & .761 & Valid \\
\hline tek2 & $<---$ & ATO & .812 & Valid \\
\hline tek3 & $<---$ & ATO & .668 & Valid \\
\hline tek4 & $<---$ & ATO & .615 & Valid \\
\hline psr1 & $<---$ & APP & .835 & Valid \\
\hline psr2 & $<---$ & APP & .735 & Valid \\
\hline psr3 & $<---$ & APP & .528 & Valid \\
\hline psr4 & $<---$ & APP & .710 & Valid \\
\hline Sumber: & Asil estimasi & & \\
\hline
\end{tabular}

Sumber: Hasil estimasi dengan AMOS 20. (2014)

Dari tabel di atas semua konvergen sebagai pengukur indikator dinyatakan memenuhi dimensi utama yaitu Internal validitas konvergen sebagai (variabel faktor-faktor internal).

pengukur masing-masing faktor Selain itu, hasil estimasi latennya. Dan faktor laten (ASDM, terstandarisir digunakan untuk AK, ATO, dan APP) juga menghitung realibilitas konstruk dinyatakan memenuhi validitas atau $C R$ dan $A V E$. 
Hasil standarized loading data

$$
\begin{aligned}
& \text { Internal }=0,755+0,896+ \\
& 0,878+0,903=3,432 \\
& \mathrm{ASDM}=0,682+0,768+ \\
& 0,788+0,770=3,008 \\
& \mathrm{AK}=0,757+0,669+\quad A P P=\frac{2,808^{2}}{2,808^{2}+1,977}=0,799 \\
& 0,806+0,611=2,843 \\
& \text { ATO }=0,761+0,812+ \\
& 0,668+0,615=2,856 \\
& \mathrm{APP}=0,835+0,735+ \\
& 0,528+0,710=2,808 \\
& \text { Hasil Measurement error loading } \\
& \text { data } \\
& \text { Internal }=0,429+0,197+ \\
& 0,229+0,184=1,039 \\
& \text { ASDM }=0,534+0,410+ \\
& 0,379+0,407=1,730 \\
& \mathrm{AK}=0,426+0,552+ \\
& 0,350+0,626=1,954 \\
& \text { ATO }=0,420+0,340+ \\
& 0,553+0,621=1,934 \\
& \mathrm{APP}=0,302+0,459+ \\
& 0,721+0,495=1,977 \\
& \text { Hasil penghitungan } C R \\
& \text { Internal }=\frac{3,342^{2}}{3,342^{2}+1,039} \\
& =0,918 \\
& A S D M=\frac{3,008^{2}}{3,008^{2}+1,730}=0,839 \\
& A K=\frac{2,843^{2}}{2,843^{2}+1,954}=0,805 \\
& \text { ATO }=\frac{2,856^{2}}{2,856^{2}+1,934}=0,808 \\
& \text { Internal }=0,755^{2}+0,896^{2}+ \\
& 0,878^{2}+0,903^{2}=2,959 \\
& \mathrm{ASDM}=0,682^{2}+0,768^{2}+ \\
& 0,788^{2}+0,770^{2}=2,268 \\
& \text { AK } \quad=0,757^{2}+0,669^{2}+ \\
& 0,806^{2}+0,611^{2}=2,043 \\
& \text { ATO }=0,761^{2}+0,812^{2}+ \\
& 0,668^{2}+0,615^{2}=2,062 \\
& \text { APP }=0,835^{2}+0,735^{2}+ \\
& 0,528^{2}+0,710^{2}=2,020 \\
& \text { Internal } \frac{2,959}{4}=0,739 \\
& A S D M=\frac{2,268}{4}=0,576 \\
& A K=\frac{2,043}{4}=0,510 \\
& \text { ATO }=\frac{2,062}{4}=0,515 \\
& A P P=\frac{2,020}{4}=0,505
\end{aligned}
$$


Tabel 7 - Hasil Pengujian Reliabilitas Variabel dan Sub Variabel Faktor Internal

\begin{tabular}{|l|c|c|c|}
\hline \multicolumn{1}{|c|}{$\begin{array}{c}\text { Variabel / Sub } \\
\text { Variabel }\end{array}$} & $\boldsymbol{C R}$ & $\boldsymbol{A V E}$ & Keterangan \\
\hline Internal & 0,918 & 0,739 & Reliabel \\
\hline ASDM & 0,839 & 0,567 & Reliabel \\
\hline AK & 0,805 & 0,510 & Reliabel \\
\hline ATO & 0,808 & 0,515 & Reliabel \\
\hline APP & 0,799 & 0,505 & Reliabel \\
\hline
\end{tabular}

Analisis Faktor Konfirmatori

Variabel Kinerja Usaha

Pada Gambar 4 model

pengukuran variabel faktor-faktor eksternal telah memenuhi kriteria sebuah model yang fit. Di mana $\chi^{2}$ (Chi-kuadrat) $\leq$ Chi-Square Table $(6,057 \leq 11,070), \quad p$-value $=0,301 \geq$ $0,05, \mathrm{RMSEA}=0,041 \leq 0,08, \mathrm{GFI}=$ $0,980 \geq 0,90$, TLI $=0,959 \geq 0,90$, dan $\mathrm{CFI}=0,979 \geq 0,90$, sehingga dapat disimpulkan model pengukuran variabel faktor internal memenuhi goodness-of-fit.

\section{Gambar 4 - Analisis Faktor Konfirmatori Variabel Kinerja Usaha}

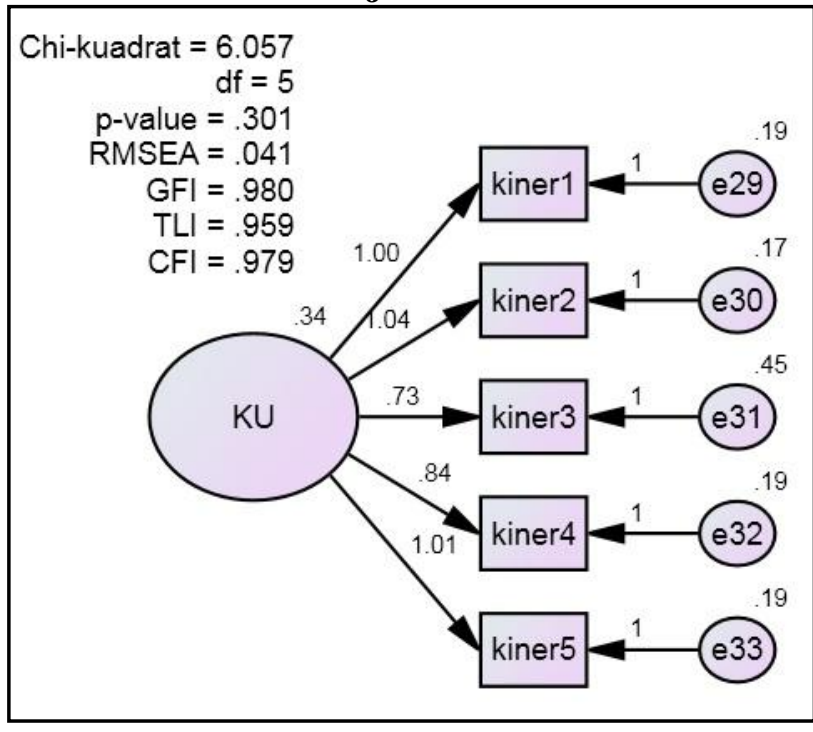

Sumber: Hasil estimasi dengan AMOS 20. (2014)

Keterangan : KU = Kinerja Usaha

Nilai signifikansi parameter dan loading faktor dari masing-masing indikator yang terdapat dalam variabel kinerja usaha dapat dilihat dalam Tabel 8 sebagai berikut: 
Tabel 8 - Hasil Estimasi

Unstandardized

Variabel Kinerja Usaha

\begin{tabular}{|l|l|l|r|r|r|r|}
\hline \multicolumn{2}{|c|}{} & & $\begin{array}{r}\text { Esti } \\
\text { mat } \\
\text { e }\end{array}$ & $\begin{array}{r}\text { S. } \\
\text { E. }\end{array}$ & C.R. & P \\
\hline kiner1 & $<--$ & KU & 1.000 & & & \\
\hline kiner2 & $<--$ & KU & 1.041 & .080 & 12.999 & $* * *$ \\
\hline kiner3 & $<--$ & KU & .732 & .121 & 6.049 & $* * *$ \\
\hline kiner4 & $<---$ & KU & .838 & .087 & 9.625 & $* * *$ \\
\hline kiner5 & $<---$ & KU & 1.010 & .087 & 11.635 & $* * *$ \\
\hline
\end{tabular}

Sumber: Hasil estimasi dengan AMOS 20. (2014)

Tiga buah asterik $(* * *)$ pada kolom $\mathrm{P}$ menunjukkan bahwa $p$ value yang dihasilkan sangat kecil yaitu lebih kecil dari 0,001. Ini berarti semua relasi dinyatakan signifikan. Dengan kata lain, semua indikator dinyatakan signifikan sebagai pengukur variabel kinerja usaha.

Hasil estimasi terstandarisir dari variabel kinerja usaha akan digunakan untuk mengukur validitas konvergen masing-masing indikator dari variabel kinerja usaha yang ditampilkan dalam Tabel 9 sebagai berikut:
Tabel 9 - Hasil Estimasi Standardized Variabel Kinerja Usaha

\begin{tabular}{|c|c|c|c|c|}
\hline & Estimate & Keterangan \\
\hline kiner1 & $<--$ & KU & .801 & Valid \\
\hline kiner2 & $<--$ & KU & .827 & Valid \\
\hline kiner3 & $<--$ & KU & .535 & Valid \\
\hline kiner4 & $<--$ & $\mathrm{KU}$ & .746 & Valid \\
\hline kiner5 & $<--$ & KU & .802 & Valid \\
\hline
\end{tabular}

20. (2014)

Dari Tabel 9 di atas dapat dilihat bahwa semua indikator dinyatakan memenuhi validitas konvergen sebagai pengukur $\mathrm{KU}$ (variabel kinerja usaha). Hasil estimasi terstandarisir juga menunjukkan dipenuhinya realibilitas konstruk atau $C R$ dan AVE.

Hasil standarized loading data

Kinerja Usaha $=0,801+0,827+$

$0,535+0,746+0,802=3,711$

Hasil measurement error loading data

Kinerja Usaha $=0,358+0,316+$ $0,713+0,443+0,356=2,186$

Hasil penghitungan $C R$

Kinerja Usaha

$$
\begin{aligned}
& =\frac{3,711^{2}}{3,711^{2}+2,186} \\
& =0,863
\end{aligned}
$$


Hasil square standardized loading

data

Kinerja Usaha $=0,801^{2}+0,827^{2}+$

$0,535^{2}+0,746^{2}+0,802^{2}=2,811$

Hasil penghitungan $A V E$

$$
\begin{aligned}
& \text { Knerja Usaha } \\
& =\frac{2,811}{5}=0,562
\end{aligned}
$$

Hasil penghitungan $C R$ dan $A V E$ akan diringkas dalam Tabel 10.

Tabel 10 - Hasil Pengujian

Reliabilitas Variabel dan Sub

Variabel

\begin{tabular}{|c|c|c|c|}
\hline $\begin{array}{c}\text { Variab } \\
\text { el / Sub } \\
\begin{array}{c}\text { Variab } \\
\text { el }\end{array}\end{array}$ & CR & $A V E$ & $\begin{array}{c}\text { Keteranga } \\
\mathbf{n}\end{array}$ \\
\hline
\end{tabular}

\begin{tabular}{|l|c|c|c|}
\hline Kinerja & 0,86 & 0,56 & Reliabel \\
Usaha & 3 & 2 & \\
\hline
\end{tabular}

Sumber : Data primer diolah (2014)

\section{Model Struktural}

Sebelum melihat apakah ada hubungan yang signifikan antara variabel-variabel eksogen dan endogen, secara overall sebuah model struktural harus dinyatakan fit. Dari Gambar 5 dan Tabel 11 di atas model struktural telah memenuhi kriteria sebuah model yang fit, sehingga selanjutnya dapat dilakukan uji hipotesis.

\section{Gambar 5 - Model Struktural}

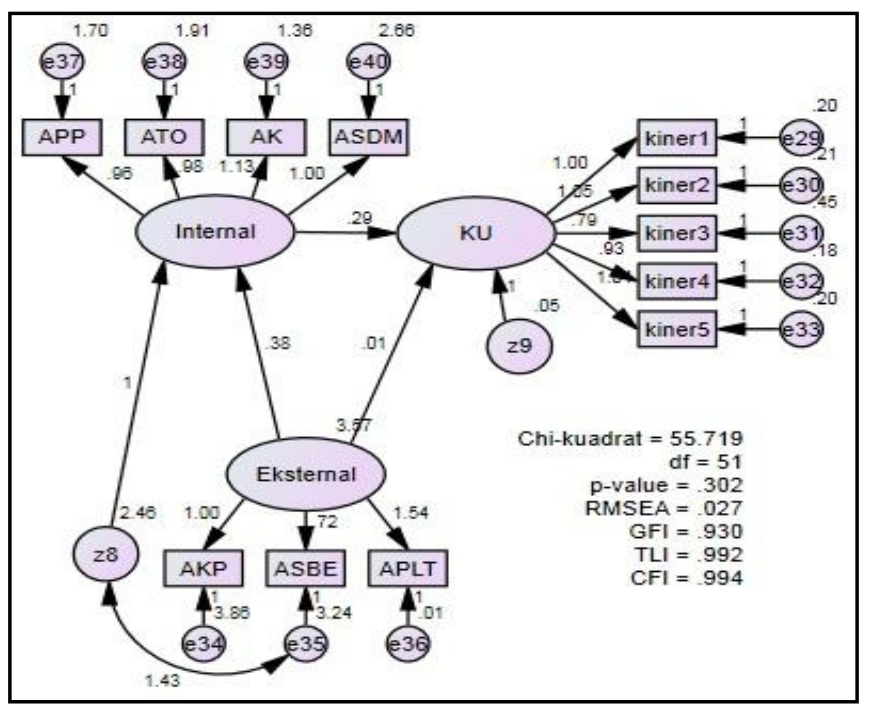

Sumber : Hasil estimasi dengan AMOS

20. (2014)

Keterangan :

AKP = Aspek Kebijakan

Pemerintah

ASBE $=$ Aspek Sosial, Budaya, dan Ekonomi

APLT $=$ Aspek Peranan Lembaga

Terkait

ASDM $=$ Aspek Sumber Daya

Manusia

$\mathrm{AK}=$ Aspek Keuangan

ATO $=$ Aspek Teknis dan

Operasional

APP $=$ Aspek Pasar dan

Pemasaran

$\mathrm{KU}=$ Kinerja Usaha 
Tabel 11 - Evaluasi Model Fit Model Struktural

\begin{tabular}{|c|c|c|c|}
\hline \multicolumn{1}{|c|}{ Indeks Fit } & Batas Penerimaan & Hasil Estimasi & Evaluasi Model \\
\hline $\begin{array}{c}\text { Statistik } \chi^{2}(\text { Chi- } \\
\text { kuadrat) }\end{array}$ & $\leq 68,669 *$ & 55,719 & Baik \\
\hline$p$-value $\chi^{2}$ & $\geq 0,05$ & 0,302 & Baik \\
\hline RMSEA & $\leq 0,08$ & 0,027 & Baik \\
\hline GFI & $\geq 0,90$ & 0,930 & Baik \\
\hline TLI & $\geq 0,95$ & 0,992 & Baik \\
\hline CFI & $\geq 0,95$ & 0,994 & Baik \\
\hline
\end{tabular}

Sumber: Hasil estimasi dengan AMOS 20. (2014)

Keterangan :

*Tabel chi-kuadrat pada $\alpha=0,05$ dan $\mathrm{df}=51$

Analisis Interpretasi Hipotesis hubungan yang signifikan antara

Penelitian

Setelah secara overall Hasil estimasi antar konstruk laten sebuah model struktural dapat dan kesimpulan yang dapat diambil dinyatakan fit, proses selanjutnya ditampilkan dalam Tabel 12 sebagai adalah melihat apakah ada berikut:

Tabel 12 - Hasil Analisis Interpretasi Signifikan Parameter

\begin{tabular}{|c|c|c|c|c|c|c|}
\hline & & & $\begin{array}{r}\text { Estima } \\
\text { te }\end{array}$ & C.R. & $\mathbf{P}$ & Kesimpulan \\
\hline Internal & $<--$ & Eksternal & .384 & 4.093 & $* * *$ & Positif dan signifikan \\
\hline KU & $\begin{array}{l}<-- \\
\end{array}$ & Eksternal & .009 & .492 & .623 & Positif dan tidak signifikan \\
\hline $\mathrm{KU}$ & $\begin{array}{ll}<-- \\
\end{array}$ & Internal & .288 & 7.554 & $* * *$ & Positif dan signifikan \\
\hline
\end{tabular}

Sumber: Hasil estimasi dengan AMOS 20. (2014) 
Kriteria pengujian adalah C.R. > 1,96 pada $\alpha=5 \%$, dan $p$-value < 0,05. Kemudian kesimpulan dari setiap hipotesis dapat diringkaskan dalam Tabel 13:

Tabel 13 - Kesimpulan Hipotesis

\begin{tabular}{|c|c|}
\hline Hipotesis & $\begin{array}{c}\text { Hasil } \\
\text { Ujii }\end{array}$ \\
\hline 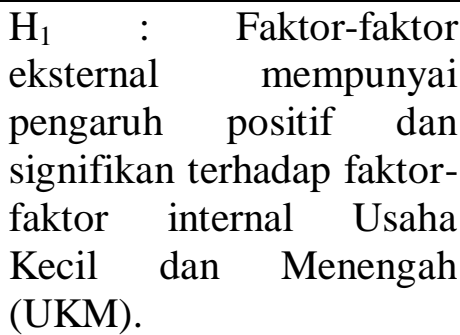 & Terbukti \\
\hline \begin{tabular}{lc}
$\mathrm{H}_{2} \quad:$ & \multicolumn{2}{c}{ Faktor-faktor } \\
eksternal & mempunyai \\
pengaruh & positif dan \\
signifikan terhadap kinerja \\
Usaha $\quad$ Kecil dan \\
Menengah (UKM).
\end{tabular} & $\begin{array}{l}\text { Tidak } \\
\text { terbukti }\end{array}$ \\
\hline $\begin{array}{l}\mathrm{H}_{3}: \text { Faktor-faktor internal } \\
\text { mempunyai pengaruh } \\
\text { positif dan signifikan } \\
\text { terhadap kinerja Usaha } \\
\text { Kecil dan Menengah } \\
(\text { UKM). }\end{array}$ & Terbukti \\
\hline
\end{tabular}

Sumber: Data primer diolah (2014)

\section{Pengaruh Faktor-faktor}

\section{Eksternal terhadap Faktor-faktor}

\section{Internal}

Pengujian telah dilakukan untuk meneliti pengaruh faktor-faktor eksternal terhadap faktor-faktor internal Usaha Kecil dan Menengah (UKM). Hasil pengujian menunjukkan bahwa faktor-faktor eksternal memiliki pengaruh signifikan dengan nilai C.R. (4,093) dan p-value $(0,000)$. Kondisi ini secara empiris menunjukkan bahwa faktor-faktor eksternal yang terdiri atas aspek kebijakan pemerintah; aspek sosial, budaya, dan ekonomi; serta aspek peranan lembaga terkait mampu mempengaruhi kualitas dari faktor-faktor internal yaitu aspek sumber daya manusia, aspek keuangan, aspek teknis dan operasional, serta aspek pasar dan pemasaran. Kualitas dari faktorfaktor internal UKM khususnya di Jakarta dapat meningkat dan mungkin memiliki kesempatan untuk berkembang menjadi usaha yang berskala lebih besar apabila faktor-faktor eksternal yang ada di sekitar lingkungan UKM mendukung secara penuh bagi perkembangan UKM. Temuan ini mendukung penelitian terdahulu dari Barney et. al. (1992) yang menunjukkan bahwa faktor-faktor eksternal mempengaruhi faktorfaktor internal bagi sebuah organisasi. Temuan ini juga mendukung temuan penelitian 
Munizu (2010) yang menemukan bahwa faktor-faktor eksternal berpengaruh positif dan signifikan terhadap faktor-faktor internal usaha mikro dan kecil, serta mendukung pernyataan Shamsuddoha et. al. (2009) bahwa kegiatan program promosi pemerintah dapat memfasilitasi pengembangan dari sumber daya dan kapabilitas UKM.

\section{Pengaruh Faktor-faktor}

\section{Eksternal terhadap Kinerja}

\section{Usaha}

Pengujian pengaruh faktorfaktor eksternal terhadap kinerja Usaha Kecil dan Menengah (UKM) menunjukkan bahwa faktor-faktor eksternal memiliki pengaruh positif namun tidak signifikan bagi kinerja UKM dengan nilai C.R. $(0,492)$ dan p-value $(0,623)$. Kondisi ini secara empiris menunjukkan bahwa para responden yang keseluruhannya adalah pemilik UKM cenderung berpendapat bahwa faktor-faktor eksternal tidak terbukti mampu mempengaruhi kinerja UKM secara signifikan. Perlu adanya perhatian khusus dari berbagai pihak terkait UKM yaitu khususnya pemerintah dan lembaga terkait untuk membantu UKM agar mampu mencapai kinerja yang lebih baik. Hal ini menunjukkan bahwa masih sulitnya UKM untuk mengakses informasi atau bantuan modal serta minimnya bimbingan dan pengetahuan mengenai adanya dukungan yang disediakan tersebut, sehingga membuat responden sulit untuk mencapai kinerja usaha yang lebih baik yaitu pertumbuhan penjualan, modal, keuntungan, pasar dan pemasaran, serta penambahan tenaga kerja. Temuan ini mendukung temuan penilitian terdahulu yang dilakukan oleh Geiger dan Hoffman (1998) yang menemukan bahwa lingkungan regulasi berpengaruh positif bagi kinerja perusahaan, namun dalam penelitian ini hasilnya tidak terlalu signifikan. Temuan ini juga mendukung temuan penelitian Munizu (2010) yang menyatakan bahwa faktor-faktor eksternal memiliki pengaruh positif terhadap kinerja usaha, namun dalam penelitiannya pengaruhnya tidak terlalu signifikan. Kemudian temuan 
ini juga mendukung temuan Barney et. al. (1992) yang menunjukkan bahwa pemerintah tidak memberikan pengaruh yang signifikan terhadap kinerja perusahaan. Kemudian Shamsuddoha et. al. (2009) yang meneliti pengaruh program promosi pemerintah terhadap kegiatan ekspor UKM dengan hasil sumber daya dan kapabilitas perusahaan adalah faktor penentu, sedangkan kegiatan program promosi pemerintah tidak meningkatkan kinerja kegiatan ekspor UKM namun hanya memfasilitasi pengembangan dari sumber daya dan kapabilitas perusahaan.

Pengaruh Faktor-faktor Internal terhadap Kinerja Usaha

Hasil penelitian ini
menunjukkan adanya pengaruh
positif dan signifikan faktor-faktor
internal terhadap kinerja Usaha
Kecil dan Menengah (UKM) dengan
nilai C.R. (7,554) dan p-value
$(0,000)$. Kondisi ini secara empiris
menunjukkan bahwa keadaan
faktor-faktor internal yang baik
yaitu aspek sumber daya manusia,

aspek keuangan, aspek teknis dan operasional, serta aspek pasar dan pemasaran akan membantu pemilik UKM untuk mencapai pertumbuhan penjualan, modal, keuntungan, pasar dan pemasaran, serta penambahan tenaga kerja. Temuan ini mendukung penelitian Acar (1993) terhadap usaha kecil di Ankara yang menyatakan bahwa perusahaan dengan kemampuan manajemen keuangan yang baik dapat mengalami peningkatan pendapatan lebih tinggi dibandingkan dengan usaha yang tidak didukung oleh kemampuan manajemen keuangan yang baik. Hasil penelitian ini mendukung temuan penelitian Munizu (2010) bahwa faktor-faktor internal memiliki pengaruh positif dan signifikan terhadap kinerja usaha. Temuan ini juga mendukung temuan penelitian Waiganjo et. al. (2012) yang berpendapat bahwa manajemen sumber daya manusia memiliki pengaruh positif terhadap kinerja organisasi untuk memperoleh keunggulan daya saing dalam pengurangan biaya, peningkatan kualitas, inovasi, dan 
pencapaian tujuan. Kemudian temuan ini juga mendukung temuan penelitian Cetin (2010) mengenai kuatnya pengaruh kinerja manufaktur, didukung kinerja sumber daya manusia dan pemasaran untuk memaksimalkan kinerja keuangan perusahaan. Temuan ini juga mendukung temuan Wispandono (2010) yang menemukan bahwa faktor internal yaitu variabel pemasaran memberikan pengaruh terbesar terhadap kinerja perusahaan.

\section{PENUTUP}

Berdasarkan hasil-hasil temuan penelitian di atas dapat dibuat simpulan seperti berikut: (1)Faktorfaktor eksternal yang terdiri dari aspek kebijakan pemerintah, aspek sosial budaya dan ekonomi, dan aspek peranan lembaga terkait memiliki pengaruh yang positif dan signifikan terhadap faktor-faktor internal UKM dengan kontribusi sebesar 0,384 atau 38,4\%; kemudian (2) Faktor-faktor eksternal memiliki pengaruh yang positif namun tidak signifikan terhadap kinerja UKM dengan kontribusi hanya sebesar
0,009 atau 0,9\%; dan (3) Faktorfaktor internal yang terdiri dari aspek sumber daya manusia, aspek keuangan, aspek teknis dan operasional, serta aspek pasar dan pemasaran memiliki pengaruh yang positif dan signifikan terhadap kinerja UKM dengan kontribusi sebesar 0,288 atau 28,8\%.

Para pemilik UKM sebaiknya tetap mempertimbangkan bahwa faktor-faktor internal yang mendominasi dalam terwujudnya peningkatan kinerja UKM seperti tingkat keterampilan, pengalaman usaha, serta jiwa kepemimpinan harus diutamakan dalam menjalankan bisnis. Faktor-faktor lain yang menjadi penghalang pemilik UKM untuk maju dapat diatasi dengan hal-hal tersebut.

Pemerintah dan lembaga terkait hendaknya mencari cara agar program yang dibuat lebih efektif membantu para pemilik UKM untuk mencapai tujuan UKM dalam menambah tenaga kerja guna mengurangi angka pengangguran dan kemiskinan, serta mencapai harapan UKM untuk mendapatkan 
pertumbuhan penjualan dan semakin banyak para pemilik UKM keuntungan. Namun tidak dapat yang bisa merasakan manfaat dari menyalahkan sepihak saja, para bantuan modal tersebut. Sebaiknya pemilik UKM juga harus aktif kegiatan pendekatan secara mencari berbagai informasi akan langsung perlu dilakukan agar adanya dukungan dan bantuan yang sosialisasi mengenai berbagai dapat dimanfaatkan guna bimbingan dan bantuan tersebut meningkatkan kinerja UKM. dapat diketahui oleh masyrakat luas

Khusus dalam bidang bantuan modal dari pemerintah dan lembaga terkait perlu ditingkatkan lagi agar efektif.

\section{DAFTAR PUSTAKA}

Acar, Ahmet C. 1993. The Impact of Key Internal Factors on Firm Performance : An Empirical Study of Small Turkish Firms, Journal of Small Business Management 31.4.

Barney, Jay B. et al. 1992. Organizational Responses to Legal Liability : Employee Exposure to Hazardous Materials, Vertical Integration, and Small Firm Production, Academy of Management Journal 32.5.

Capps, Charles J. dan Michael D. Glissmeyer. 2012. Extending The Competitive Profile Matrix Using Internal Factor Evaluation and External Factor Evaluation Matrix Concepts, Journal of Applied Business Research 28.5.

Cetin, Ayze Tansel. 2010. The Effects of Human Resource Marketing and Manufacturing Performance on Financial Performance, Journal of Global Strategic Management 7.

Dachlan, Usman. 2014. Panduan Lengkap Structural Equation Modeling Tingkat Dasar, Edisi Pertama, Lentera Ilmu, Semarang. 
David, Fred R. 2009. Strategic Management: Concepts and Cases, Twelfth Edition, Pearson Prentice Hall, New Jersey.

El-Chaarani, Hani. 2014. The Impact of Financial and Legal Structures on The Performance of European Listed Firms, The International Journal of Business and Finance Research 9.2.

Geiger, Scott W., and James J Hoffman. 1998. The Impact of the Regulatory Enviroment and Corporate Level Diversification on Firm Performance, Journal of Managerial Issues 10.4.

Juliandi, Azuar et al. 2014. Metodologi Penelitian Bisnis : Konsep dan Aplikasi, UMSU Press, Medan.

Munizu, Musran. 2010. Pengaruh Faktor-faktor Eksternal dan Internal terhadap Kinerja Usaha Mikro dan Kecil (UMK) di Sulawesi Selatan, Jurnal Manajemen dan Kewirausahaan Vol.12 No.1.

Pearce, John A. dan Richard B. Robinson. 2011. Strategic Management Formulation, Implementation, and Control, Twelfth Edition, McGrawHill, New York.

Rangkuti, Freddy. 2013. Analisis SWOT Teknik Membedah Kasus Bisnis, Gramedia, Jakarta.

Shamsuddoha, A K. et al. 2009, A Conceptualisation of Direct And Indirect Impact of Export Promotion Programs on Export Performance of SMES And Entrepreneurial Ventures, International Journal of Entrepreneurship 13.

Waiganjo, Miss Esther Wangithi et al. 2012. Relationship between Strategic Human Resource Management and Firm Performance of Kenya's Corporate Organizations, International Journal of Humanities and Social Science Vol. 2 No.10.

Wispandono, R. M. Moch. 2010. Pengaruh Lingkungan Bisnis terhadap Kinerja Industri Batik di Kabupaten Bangkalan, Jurnal Mitra Ekonomi dan Manajemen Bisnis, Vol.1 No.2. 
Wei, Li-qun dan Chung-ming Lau. 2008. The Impact of Market Orientation and Strategic HRM on Firm Performance: the Case of Chinese Enterprises, Journal of International Business Studies 39.6.

Zimmerer, Thomas W. et al. 2008. Kewirausahaan dan Manajemen Usaha Kecil, Edisi Kelima, Salemba Empat, Jakarta. 


\section{INDEKS PENULIS JURNAL}

Howard S. Giam adalah dosen pada Program Studi Manajemen, Fakultas Ilmu Sosial dan Humaniora, Universitas Bunda Mulia. Konsentrasi bidang ajar pada mata kuliah Manajemen dan Bisnis.

Fahrul Riza adalah dosen pada Program Studi Manajemen, Fakultas Ilmu Sosial dan Humaniora, Universitas Bunda Mulia. Konsentrasi bidang ajar pada mata kuliah Ekonomi Manajerial, Ekonomi Mikro dan Ekonomi Makro.

Alexander Joseph Ibnu Wibowo adalah dosen pada Prasetya Mulya Business School, Konsentrasi bidang ajar pada mata kuliah Manajemen Pemasaran, Perilaku Konsumen dan Statistik.

Hendy Tannady adalah dosen pada Program Studi Teknik Manajemen Industri, Fakultas Teknik dan Disain, Universitas Bunda Mulia. Konsentrasi bidang ajar pada mata kuliah Manajemen Operasional.

Dino Caesaron adalah dosen pada Program Studi Teknik Manajemen Industri, Fakultas Teknik dan Disain, Universitas Bunda Mulia. Konsentrasi bidang ajar pada mata kuliah Manajemen Operasional

Arry Widodo adalah dosen pada Fakultas Ekonomi Universitas Telkom. Konsentrasi bidang ajar pada mata kuliah Manajemen Keuangan.

Renda Puspita Dewi adalah dosen pada Fakultas Ekonomi Universitas Telkom. Konsentrasi bidang ajar pada mata kuliah Manajemen Keuangan.

Julyana Wijaya adalah dosen pada Program Studi Manajemen, Fakultas Ilmu Sosial dan Humaniora, Universitas Bunda Mulia. Konsentrasi bidang ajar pada mata kuliah Manajemen Keuangan.

Alex Sandra adalah mahasiswa Program Studi Manajemen Universitas Bunda Mulia peminatan General Management.

Edi Purwanto adalah dosen pada Program Studi Manajemen, Fakultas Ilmu Sosial dan Humaniora, Universitas Bunda Mulia, Konsentrasi bidang ajar pada mata kuliah Manajemen Strategi dan Dinamika Persaingan Global. 


\section{INDEKS MITRA BESTARI}

Prof. Dr. Ir. Sony Heru Priyanto, MM adalah Dekan Fakultas Pertanian dan Bisnis, Universitas Kristen Satya Wacana, Salatiga, Jawa Tengah. Beliau menyelesaikan pendidikan S-1 (Ir.) dari Universitas Gadjah Mada, Yogyakarta tahun 1990, S-2 (MM) di universitas yang sama pada tahun 1996 dan S-3 (Dr.) dari Universitas Brawijaya, Malang. Tulisan-tulisan beliau dipublikasikan di sejumlah jurnal nasional maupun internasional seperti, Journal of Economics and Business (2002), International Journal of Entrepreneurship and Innovation Management (2005), Gadjah Mada International Journal of Business (2006), Basic Research Journal of Business Management and Accounts (2012).

Prof. John JOI Ihalauw, SE, Ph.D. meraih gelar Sarjana Ekonomi pada tahun 1967 dari Fakultas Ekonomi Universitas Kristen Satya Wacana, Salatiga. Gelar Ph.D. dicapai di Iowa State University, USA, tahun 1979. Pernah menjawab Direktur Lembaga Penelitian Ilmu-Ilmu Sosial - UKSW (197301975); Dekan FE-UKSW (1979-1983); Pembantu Rektor Bidang Akademik - UKSW (19831988); Dekan FE-UKRIDA Jakarta (1989-1993); Rektor UKSW (1993-2001), Direktur Program Pascasarjana UKSW (1999-2003), Dean - UPH Business School (2007-2008) dan Advisor to UPH-Business School dan Director of Strategic Planning and Cooperation with Industries-UPH Business School. Selain bidang akademik, beliau juga memiliki sejumlah pengalaman sebagai Presiden Direktur PT Prafa, Jakarta (1990-1993); Direktur PT Pradja Farma Hoslab, Jakarta (1990-1993); Komisaris PT Prima Alkesindo Nusantara, Jakarta (1997-2003); Direktur PT Mekar Armada Jaya (New Armada, 20032005) dan sebagai konsultan di berbagai agensi internasional. Karya-karya beliau telah dipublikasikan di sejumlah jurnal nasional maupun internasional. Beliau menulis buku Konstruksi Teori: Komponen dan Proses diterbitkan oleh Grasindo, 2008. 


\section{KETENTUAN PENULISAN BUSINESS MANAGEMENT JOURNAL}

Business Management Journal merupakan jurnal ilmiah Program Studi Manajemen Universitas Bunda Mulia yang diperuntukan sebagai media komunikasi ilmiah untuk diseminasi hasil penelitian maupun tinjauan pemikiran bisnis dan manajemen. Jurnal ini terbit dua kali dalam setahun (Maret dan September). Bagi para pembaca yang memiliki hasil tulisan ilmiah yang belum pernah dipublikasikan dapat mengirimkannya kepada tim redaksi di alamat email friza@bundamulia.ac.id, atau epurwanto@bundamulia

\section{Persyaratan Isi Naskah}

- Materi karya ilmiah memiliki relevansi dengan kajian dalam bidang ilmu manajemen (Pemasaran, Keuangan, SDM, Kewirausahaan).

- Belum pernah dipublikasikan di media apapun, baik cetak maupun online.

- Hasil penelitian baik yang bersifat empirik ataupun studi literatur (penelitian kepustakaan) ataupun citation analysi, Analisis atas data sekunder,Tinjauan kritis atas suatu buku (book review)

\section{Format Penullisan}

- Naskah ditulis dalam bahasa Indonesia dengan memperhatikan kaidah-kaidah bahasa yang baku dengan jumlah halaman antara 20-30 halaman, dengan spasi 1,5 (tipe font: times new roman, ukuran 12) di kertas ukuran A4.

- Abstrak terdiri atas dua bahasa (Inggris dan Indonesia) maksimal panjang 125150 kata,

- Kata kunci terdiri dari 4 atau 5 kata atau frasa

\section{Kerangka naskah studi literatur}

- Judul (Huruf Besar, Times New Roman, Ukuran 14, Bold)

- Nama Penulis (Lengkap dan tanpa gelar)

- Alamat email penulis.

- Institusi atau lembaga asal penulis.

- Abstrak.

- Kata Kunci.

- Pendahuluan.

- Rerangka Konseptual dan Hipotesis.

- Metode Penelitian.

- Hasil dan Pembahasan.

- Penutup

- Daftar Pustaka

\section{Kerangka naskah studi literatur}

- Judul (Huruf Besar, Times New Roman, Ukuran 14, Bold)

- Nama Penulis (Lengkap dan tanpa gelar)

- Alamat email penulis.

- Institusi atau lembaga asal penulis.

- Abstrak.

- Kata Kunci.

- Pendahuluan.

- Tinjauan Kepustakaan

- Pembahasan

- Penutup

- Daftar Pustaka 